\title{
European Bee-eater (Merops apiaster Linnaeus, 1758) in Hungary: a review
}

\author{
József Gyurácz ${ }^{1}$, Károly Nagy ${ }^{2}$, Tibor István Fuisz ${ }^{3}$, \\ ZsOlT KarcZA ${ }^{2} \&$ TibOR SZÉP 4
}

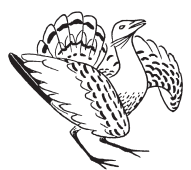

József Gyurácz, Károly Nagy, Tibor István Fuisz, Zsolt Karcza \& Tibor Szép 2013. European Bee-eater (Merops apiaster Linnaeus, 1758) in Hungary: a review. - Ornis Hungarica 21(2): 1-22. Year' in Hungary offers the possibility to summarise the information about the distribution, population size, breeding and feeding ecology, dispersion, migration, intra- and interspecific relationships as well as the nature conservation status of the bee-eater population breeding in Hungary. Though this review focuses on the Hungarian population trends, but also summarises the major research results from other countries. In the period of 1992-2013, the number of breeding pairs were surveyed in $58972.5 \times 2.5 \mathrm{~km}$ UTM squares in the frame of the Monitoring of Rare and Colonial Breeding Birds programme. In the surveyed area during the period of 1992-2013, the most accurate estimate suggests a 10600-19600 breeding pair population. The larger nesting colonies were observed in the following regions: Zala Hills, Outer Somogy, Gerecse, Velencei Hills, Mezőföld, Gödöllő Hills, Tápió, Bükkalja, Taktaköz, Körös region. The annual population indices showed marked fluctuation with stable long term population trend in Hungary. The national monitoring and protection project of the European Bee-eater revealed the most important factors endangering the nesting populations, these are weed invasion and the collapse of vertical banks, mining carried out in the nesting period and direct human-caused disturbance (e.g. shooting, tourism).

Keywords: Merops apiaster, Hungary, breeding population, migration, conservation

Összefoglalás A gyurgyalag (Merops apiaster Linnaeus, 1758) „méhész madárként” és hatékony ökoszisztéma mérnök fajként is ismert. 2013-ban „Az év madarának” választották Magyarországon, ezen alkalomból jelen írás összefoglalja a gyurgyalag földrajzi elterjedésére, állománynagyságára, fészkelésére, táplálkozására, szétterjedésére, vonulására, intra- és interspecifikus kapcsolataira, valamint természetvédelmi helyzetére vonatkozó lényeges ismereteket, kitekintve más országok fontosabb kutatási eredményeire is. 1992 és 2013 között, az MME „Ritka és Telepesen fészkelő Madarak Monitroingja, RTM” program keretében 5897 darab, 2,5×2,5 kilométeres UTM négyzetben mértük fel a költőpárok számát. Felméréseink alapján készült eddigi legpontosabb becslés szerint a gyurgyalag hazai fészkelő állománya évente 10 600-19 600 pár volt 1992 és 2013 között. A legnagyobb költőtelepeket a következő régiókban figyeltük meg: Zalai-dombság, Külső-Somogy, Gerecse, Velencei-hegység, Mezőföld, Gödöllöi-dombság, Tápióvidék, Bükkalja, Taktaköz, Körös vidéke. A trendanalízis eredménye alapján a hazai költőállomány a vizsgált időszakban stabil volt. Az országos monitoring és védelmi program által feltárt leggyakoribb fészkelést veszélyeztető tényezők a következők voltak: a partfalak benövényesedése, a függőleges partfalak ledőlése, fészkelési időszakban végzett bányászat, valamint a közvetlen emberi zavarás (pl. vadászat, turizmus).

Kulcsszavak: Merops apiaster, Magyarország, költő populáció, vonulás, védelem

${ }^{1}$ Institute of Biology, Faculty of Sciences, University of West Hungary, Szombathely, Károlyi Gáspár tér 4., 9700 Hungary,e-mail: gyjozsi@ttk.nyme.hu

${ }^{2}$ MME/BirdLife Hungary, Budapest, Költö utca 21., 1121 Hungary, e-mail:nagy.karoly@mme.hu, karcza.zsolt@ mme.hu

${ }^{3}$ Department of Zoology, Bird Collection, Hungarian Natural History Museum, Budapest, Baross u. 13., 1088 Hungary, e-mail: tibori.fuisz@gmail.com

${ }^{4}$ Institute of Environmental Sciences, College of Nyiregyháza, Nyíregyháza, Sóstói út 31/b, 4400 Hungary, e-mail: partifecske@freemail.hu 


\section{Introduction}

The 27 colorful and morphologically uniform species of the Meropidae family is divided into three genera (Dickinson \& Remsen 2013). The three species belonging to the Nyctiornis (2 species) and Meropogon (1 species) genera are confined to the far East, from the Himalaya mountains to Sulawesi, while the 24 species of the Merops genus can be divided into two biogeographical and ecological species clade on the basis of phylogenetic analysis (Dickinson 2003). One of them consists of the resident species that are breeding in Africa, while the species of the other clade are obligatory migrants and breed in Africa and Eurasia (Marks et al. 2007) and one species even in Australia. The Persian Bee-eater (Merops persicus Pallas, 1773) belongs to the latter clade, and occasionally nests in SouthEast Europe (Cramp 1998), however, the European Bee-eater (Merops apiaster Linnaeus, 1758) is fairly common, widespread and regular, colonial breeder in Europe (Fry 1984, Cramp 1998). This species has been breeding in Hungary and the surrounding area since the middle-Pleistocen (Udvardy 1969, Mlíkovský 2009). The area of the species is extended northwards in Europe, and it appeared in areas like the north of Hungary during the last centuries because of the milder winters and warmer average spring temperatures caused by global climate change (Kinzelbach et al. 1997). It has still been expanding in Northern Europe in the last decade (Vagg \& Hepworth 2006).

In Hungary, the European Bee-eater has been protected since 1954, it became a strictly protected species in 1984. Furthermore it is listed in the National Red Book (Bankovics et al. 1989), in the list of the 71 most endangered terrestrial vertebrate species of
Hungary (Báldi et al. 2001), as well as in the Second Appendices of the Bern and Bonn Conventions (Heath et al. 2000). The European Bee-eater was selected for the title 'The Bird of the Year' for the first time, by BirdLife Hungary in 1979 (Kállay 1978). The national monitoring and protection project for the European Bee-eater started due to insufficient nesting and distribution data of the species. Nature conservation conflicts arose from the bee-eaters' nesting site preference and consumption of Western Honeybees (Apis mellifera). The Hungarian European Bee-eater monitoring and conservation program was launched with the following goals:

- to survey the number and distribution of breeding pairs,

- to identify the risk factors for breeding and nest sites,

- to reduce the degradation of nests and breeding sites,

- to change people's attitude towards the species and the natural environment (Gyurácz 1998a, Gyurácz et al. 2004).

Between 1992 and 2013, the number of breeding pairs were surveyed in 5897 $2.5 \times 2.5 \mathrm{~km}$ UTM squares in the frame of Monitoring of Rare and Colonial Breeding Birds Programme (Ritka és Telepesen Fészkelő Madarak Monitoringja, RTM) (minimum in 1992: 29 squares, maximum in 2002: 806 squares) (Figure 1). From the 5897 UTM squares there were 1136 pieces, which were surveyed at least in three different years and which UTM squares were used for estimating trends for the period of 1992-2013 by TRIM software (McCullagh \& Nelder 1989, Pannekoek \& van Strien 2001, van Strien et al. 2001).

The results of the more than twenty years long monitoring and protection program and the fact that in 2013, once again the European Bee-eater became 'The Bird of the 


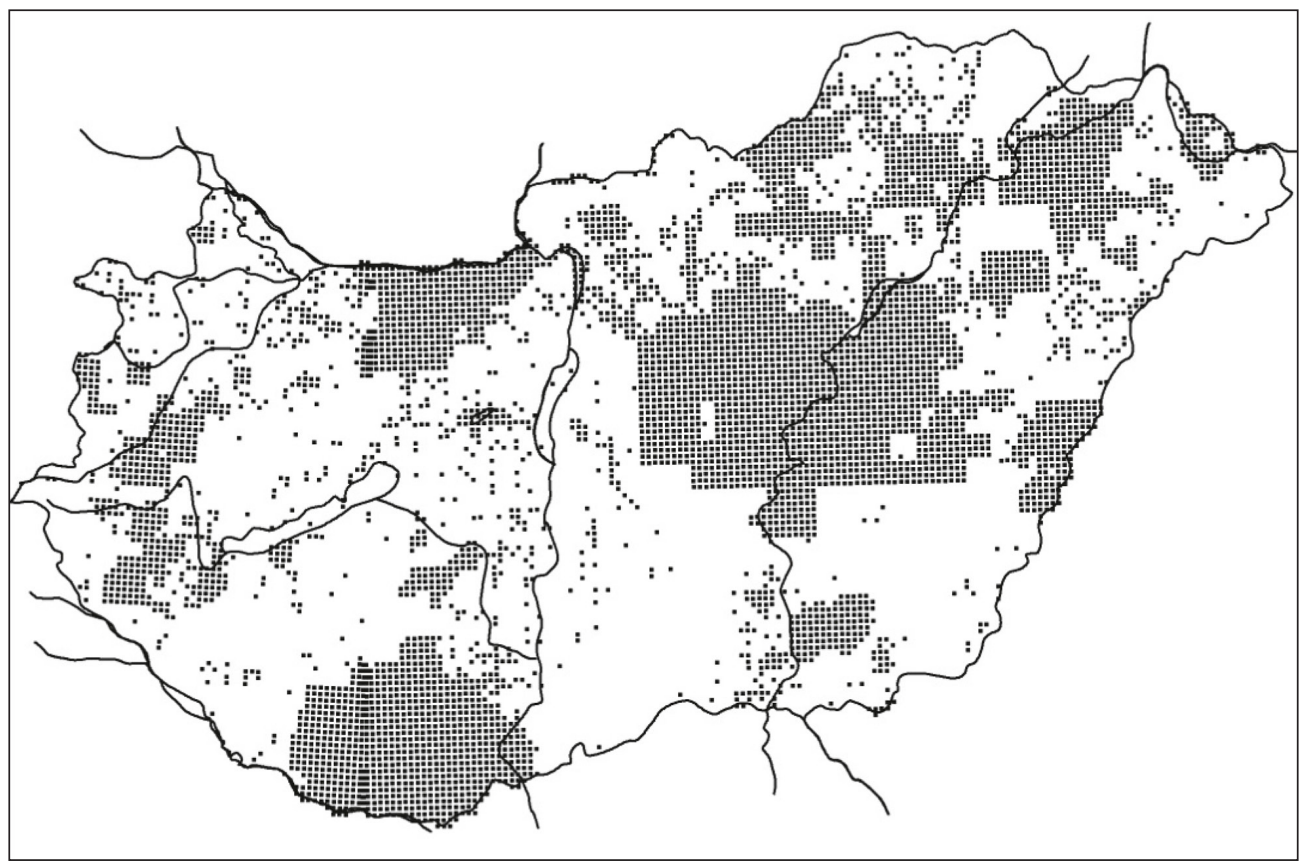

Figure 1. Distribution of $2.5 \times 2.5 \mathrm{~km}^{2}$ UTM squares in Hungary where number of breeding pairs of European Bee-eaters was surveyed (including zero observation) during 1992-2013

1. ábra A felmért 2,5×2,5 km²-es UTM négyzetek eloszlása Magyarországon 1992-2013 között

Year' in Hungary (Bagdi 2013), gives an excellent opportunity to summarise the information about the distribution, population size, behaviour and the nature conservation status of the Bee-eater population breeding in Hungary. Though this review focuses on the Hungarian population trends, but also summarises the major research results from other countries as well.

\section{Geographical distribution}

The current area of the European Bee-eater expands from North Africa through the Iberian Peninsula, Southern Europe, the Carpathian Basin, Eastern Europe, Smalland Mid-Asia to Kashmir due to postglacial dispersal (Cramp 1998, Snow \& Perrins 1998). A few smaller population breeds in
South Africa (Fry 1984). The northern border of the area coincides with the $21^{\circ} \mathrm{C}$ isotherm of July, but exceptionally some birds expand to the $17{ }^{\circ} \mathrm{C}$ isotherm of July (Fry 1984, Krištín \& Petrov 1997).

In Europe, the data gathered on its distribution changes revealed the northward expansion of the European Bee-eater from the 1920s and 1930s and its westward expansion from the second half of the 1940s (Fry 1984, Cramp 1998). The European Bee-eater appeared as nesting species due to this area expansion and even its occasional nesting was recorded in further northern regions like in Northern France, the Netherlands, Denmark, Britain, Finland and Russia (Krištín \& Petrov 1997, Cramp 1998).

The European Bee-eater was an uncommon bird until the middle of the twentieth century in Hungary, only the nesting of a 
few sporadic breeding pairs were published in journals including ornithological sources (Aizenpreisz 1929, Máry 1929, Réz 1929, 1932, Sőreghy 1934, Porgányi 1935, Schenk 1935, Páldy 1935, 1939, Radványi 1939, Vertse 1939, Sághy 1942a, 1942b, Thóbiás 1943, Keller 1949, Breuer 1950, Molnár 1950, Dorning 1955, Sághy 1955, Bókai 1957, Randik 1957, Vásárhelyi 1957, Beretzk 1959, Sterbetz 1959, Mile 1964, Halmosi 1978, Keve 1978, Kis 1978a, 1978b, Sághy 1978, Gyovai 1979, Nagy 1979, Radetzky 1979a, 1979b, Horváth 1980, Leposa 1980, Keve 1981, Kovács 1981, Bali 1982, Szalczer 1982, Varga 1982, Lenner 1983, Barta 1998), but migratory birds (Csapó 1918, Greschik 1938, Lenner 1982, Kagyerják 1983) and simple faunistic observations have also been reported in scientific articles (Uhde 1905, Tarján 1929, Rainer 1930,
Gönye 1935, Wagner 1935, Merán 1947, Dorning 1949, Sőregi 1955, Bécsy 1966, Farkas 1967, Buschmann \& Mester 1988, Kárpáti 1989). In Hungary, its nesting was only proven in the area bordered by the Danube, Drava rivers and Balaton Lake before 1940 (Radványi 1936, Keve 1949), and it expanded to the northwestern part of Hungary (Keve \& Udvardy 1951) after 1940. The breeding population concentrated in a handful of sites in the twentieth century (Szijj 1955): there were some major colonies in Tolna County of Southern Transdanubia (Lokcsánszky 1935, Radványi 1936, 1939), Baranya and Fejér Counties (Radetzky 1966, 1979a, 1979b, Halmosi 1978, Tapfer 1978). A lot of nesting data were known from the Gödöllő Hills (Vertse 1939, Dorning 1955, Papp 1980, 1984, Jáky 1990, Kertész 1986, 1991a, 1991b). More significant colonies

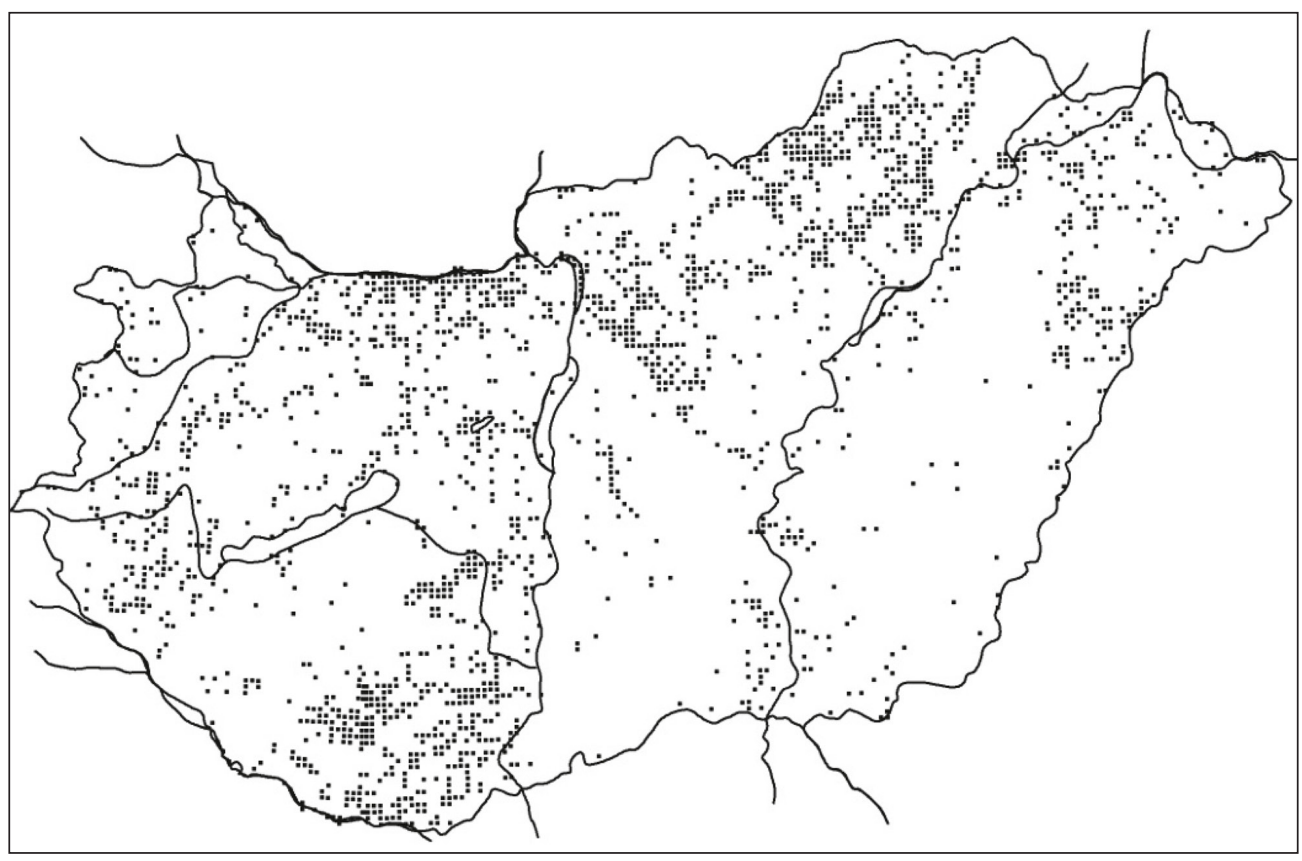

Figure 2. Distribution of $2.5 \times 2.5 \mathrm{~km}^{2}$ UTM squares in Hungary where breeding pairs of European Beeeaters were observed during 1992-2013

2. ábra A 2,5×2,5 $\mathrm{km}^{2}$-es UTM négyzetek eloszlása Magyarországon, ahol a gyurgyalag fészkelt 1992-2013 között 
formed around Tokaj in Northern Hungary (Radványi 1950, 1964, Mercsák \& Mercsák 1980 ) and along the Szamos river in NorthEast Hungary (Sőreghy 1934, Sőregi 1955, Fintha 1968, 1969). Recently the majority of the breeding population is found in Zala, Baranya, Komárom-Esztergom, Tolna, Fejér, Pest, Borsod-Abaúj-Zemplén and Szabolcs-Szatmár-Bereg Counties according to the surveys conducted since 1992 (Figure 2).

\section{Nesting population}

The European nesting population of the European Bee-eater was estimated between 86000 and 380000 pairs (with birds nesting in Turkey included) at the end of 1980s (Fry 1994), between 92000 and 390000 pairs in the late 1990s (Heath et al. 2000) and more than 480000 pairs in the early 2000s (BirdLife International 2004). Europe involves $25-49 \%$ of the global range, so a very preliminary estimate of the global population size can be more than 1470000 breeding pairs (BirdLife International datazone 2013). The population was not evenly distributed, $44 \%$ of the birds bred at the Iberian Peninsula, $26 \%$ of them bred at the Balkans and the remaining $23 \%$ of the birds bred in East Europe (Krištín \& Petrov 1997).

In Austria the European Bee-eater breeds in Burgenland and Lower Austria (Dvorak et al. 1993). Its national population was around 250-360 pairs in 1995-97 (Heath et al. 2000), there were 81 breeding pairs in Northern Burgenland and 102 breeding pairs in Lower Austria in 2000 (Knogler in litt., in Ragats 2001). At least 700-1000 pairs breed in Slovakia and their number have been steadily rising (Murin et al. 1994).

In Romania, the European Bee-eater was regularly nesting everywhere in the sou- thern and the eastern parts, while only sporadically in Transylvania (Muntenau 1998). The national breeding population was estimated between 10000 and 20000 pairs in Romania (BirdLife International 2004). In Northern Serbia (Vojvodina), 1000-2000 nesting pairs were estimated between 1987 and 1990 (Purger 2001).

The first census of the breeding population was conducted in 1949 in Hungary and 1271 pairs were recorded at 59 colonies, out of which 986 pairs nested in Transdanubia (Szijj 1955). About 2000 breeding pairs were estimated in 1955 (Tapfer 1957). In 1977, Glutz von Blotzheim and Bauer (1980) cited Sterbetz and assumed 1350 breeding pairs in Hungary at the known nesting sites. These surveys might not have been complete, consequently the real population number could have been two or three times higher (Fry 1984). 203 colonies and 1761 breeding pairs were counted in the survey conducted in 1984 (Haraszthy in litt., in Ragats 2001). In the early 1990s, the Hungarian breeding population of the European Bee-eater was estimated around 1000-3000 pairs (Bankovics 2000) and 3000-5000 pairs were estimated in the second half of the '90s (Magyar et al. 1998). More exact data on the Hungarian breeding population of the European Bee-eater was obtained by the regional and county population monitoring programmes, organised in the last decade of the $20^{\text {th }}$ and early $21^{\text {st }}$ century (Jánoska 1993, Gyurácz \& Szanyi 1994a, 1994b, Alexay 1997, Rakonczay 1997, Lajtmann 1998, Bagdi 1999a, 1999b, Gyurácz 1999, 2000, Ragats 2001, Farkas et al. 2003, Batta \& Misik 2008, Gyurácz 2012). Furthermore BirdLife Hungary started in 1992 the national survey for this species. However, the surveys did not cover the whole country. 
Based on the available monitoring data, the estimated Hungarian European Bee-eater population was 20000-30000 breeding pairs in the 1990s (Gyurácz \& Nagy 1999, 2000, 2001, Gyurácz 2000). Based on the surveys conducted between 1998 and 2003, there were less than 20 breeding pairs per colony in more than $92 \%$ of the breeding sites and $64 \%$ of the surveyed population nested in these small colonies (Nagy et al. 2008). Colonies with fifty or more pairs constitute 1-3 percent of all surveyed colonies, and 10 percent of the surveyed nesting pairs bred at these larger nesting sites. The larger colonies are typical in the following regions: Zala Hills, Outer Somogy, Gerecse, Velencei Hills, Mezőföld, Gödöllő Hills, Tápióság, Bükkalja, Taktaköz, Körös region. In 2012 the nesting pairs of the Albertirsa (Gödöllő Hills) colony were close to 300 , so this was the largest known colony in Hungary, and possibly in Central-Europe (Urbán et al. 2013).

In the surveyed area during the period of 1992-2013, the most accurate estimate suggests a 10600-19600 breeding pairs po- pulation. The annual population indices showed marked fluctuation (Figure 3) with stable population trend (slope $=0.890 \%$, $\mathrm{SE}=0.480 \%$ ) based on the trend classification of the TRIM. The estimated trend of Bee-eater population during 1992-2013 (RTM) showed difference from the trend estimated in the frame of the Hungarian Common Bird Monitoring (Mindennapi Madaraink Monitoringja, MMM) (Szép et al. 2013). The MMM showed significant decreasing trend (slope $=-5.6 \%, \mathrm{SE}=2.8$, $\mathrm{P}<0.05$ ) for this species in Hungary between 1999-2012. To understand this difference one need to consider the different selection of the investigated UTM squares during the survey of breeding pairs in the frame of RTM, which based on free choice and focused mainly on the potential breeding habitats. In the case of MMM, the selection of investigated UTM squares was based on random sampling, covering the main habitat types of Hungary. In the case of MMM, the number of foraging bee-eaters is observed and the MMM trend refer

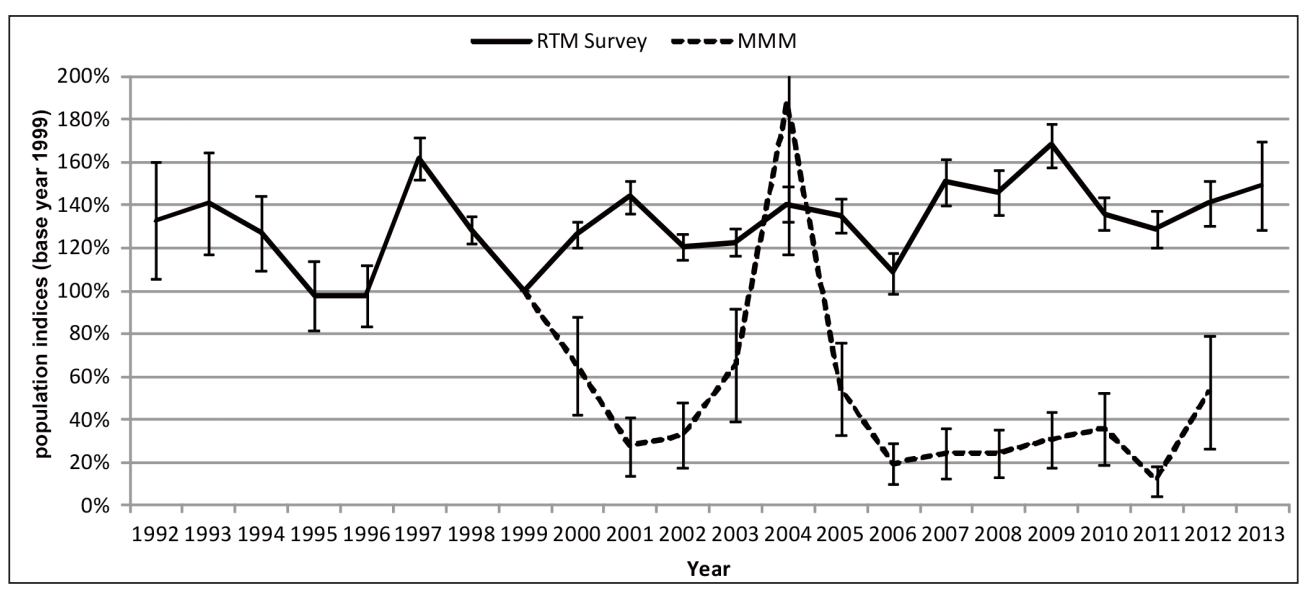

Figure 3. Annual population indices $( \pm S E)$ of the surveyed European Bee-eater population in the frame of the RTM survey during 1992-2013 and in the frame of the MMM during 19992012 (Szép et al. 2013), based on TRIM imputed index. Base year was 1999

3. ábra A gyurgyalag felmérés évi populációs indexei 1992-2013 között az RTM, és 1999-2012 között (Szép et al. 2013) az MMM keretében felvéve. Alapév 1999 
mainly to the number of foraging individuals in the dominant type of habitats (cultivated farmland) in Hungary. The difference between the trends of RTM and MMM survey could reflect either different trends of the breeding populations or different trends in the use of farmland habitats for foraging by the bee-eaters in Hungary. The RTM programme need to be extended to all potential breeding sites of the country in order to refine the estimate of the population size and discover the trends of its change.

\section{Breeding ecology}

The European Bee-eater is considered an effective ecosystem engineer bird, as it excavates tunnels ending in a nesting chamber into the natural or artificial vertical loessand sandbanks, the walls of sand quarries, as well as river banks, and hence significantly contributes to the air circulation of the soil (Ar \& Pionkiewitz 1992, Casas-Criville \& Valera 2005). The spatial distribution of the nesting populations is mainly determined by the surface presence of loess and sand, but other chemical and physical properties of the soil also play an important role (Smalley et al. 2013). In Hungary, 6065 percent of nesting sites were located in the actively used or closed sand-mines, and 55-65 percent of the breeding pairs bred in these mines recently.

The proliferation of sand, gravel and other building material extraction sites due to the intensive road and housing constructions in the second half of the $20^{\text {th }}$ century may have contributed to the increase and expansion of the European Bee-eater breeding population in our country. The vertical banks of mines lacking vegetation provided excellent nesting opportunities for the bee-eaters. The birds could find undisturbed nesting conditions primarily in the closed, non-used sand-mines. However, the mines, in which the production has been stopped for a long time, were finally abandoned by the birds because of two reasons. Firstly, the vertical banks were cut to askew according to law in the closed mines. Secondly the re-growth of vegetation on the banks prevents the excavating of the nestingholes and settling of birds. Colonies with more than hundreds of pairs existed in previous surveys, but they are not typical currently in Hungary. One or some pairs can dig their nesting-holes in small-scale land surfaces without vegetation, such as banks of linear facilities (roads, railways, channels). Some bee-eaters could occasionally also settle in a pit of constructions, sand and loess grasslands or roadsides.

The breeding-site preference of the European Bee-eater was investigated by several foreign and Hungarian studies. The soil's particle size, its hardness, slope, exposure and vegetation cover of the banks, and the distance of the bank from the next forest and settlement could all influence the habitat choice of the bee-eaters (Gyovai 1993, Gyurácz \& Szanyi 1994b, Nagy 1996, Heneberg \& Šimeček 2004). The mean particle size of soil samples from bee-eater nest colonies was $42.76 \pm 13.58 \mu \mathrm{m}$. Mean particle size differed significantly between samples from European Bee-eater and Sand Martin nest places. There were no bee-eater nests in the soils containing particles over 10,000 $\mu \mathrm{m}$. The samples from bee-eater colonies contained 20 times more soil grains between 28.0 and $9.2 \mu \mathrm{m}$ than in those from sand martin holes. These significant differences may explain why these two species do not usually breed in same cliffs (Heneberg \& Šimeček 2004). Paying attention on the hardness of the soil, more than half of 
the nesting colonies were made in sandy loam in the Pannonhalma Hills (Lajtmann 1998). According to Gyovai's (1993) South Great Plains study, the average length of the excavated nesting tunnels was $147 \mathrm{~cm}$ (min. $135 \mathrm{~cm}, \max .170 \mathrm{~cm}$ ) in the heavier soils and it was $106 \mathrm{~cm}$ (min. $90 \mathrm{~cm}$, max. 120 $\mathrm{cm}$ ) in the soft soils, respectively. The type of soil and the slope of the hillside and bank also had an effect on the lenght of the nesting tunnels. The bee-eaters choosed lower slopes on sand than on loess in the Gödöllöi Hills (Kerényi \& Ivók 2013).

The egg-laying of the European Bee-eater begins in mid-May, but may be delayed until early July in Hungary. In extreme cases, such as the very late beginning of the laying in 2013 might result in females still developing eggs in mid August (Vas, Z. \& Fuisz, T. I. pers.com.). The female lays 5-8 eggs with 1-5 day intervals, the incubation time is 20-22 days and the chicks can be fledged out at around 30 days of age (Bankovics 2000). Gyovai's (1993) study gave a detailed description of the nesting cavity, documented the digging of the tunnel, egg-laying, incubation and development of the nestlings. Large colonies could only develop in properly large vertical banks. Nagy (1996) found in the Upper Tisza region that the size of the breeding colonies was correlated with the bank length, but did not correlate with the surface of the bank. In this region, the long, but not too high riverbanks were typical. According to the Little Plain studies (Ragats 2001) there was no strong correlation between the bank surface or length and the number of nesting pairs. Batta and Misik (2008) observed that the bee-eaters preferred banks with smaller surface. Instead of concave parts, flat and convex areas of the banks were preferred by bee-eaters. The birds' view was better from the nesting-holes prepared in convex banks, so they were safer in these holes and the start of digging was easier in convex banks than the concave ones (Gyovai 1993). About two-thirds of the nesting cavities were made in one meter band measured from the top of the bank (Gyovai 1993, Gyurácz \& Szanyi 1994a, Batta \& Misik 2008).

According to the national studies, the distance of the banks from the forests did not play a serious role in the breeding habitat choice of the European Bee-eaters (Gyurácz \& Szanyi 1994b, Ragats 2001), but they preferred banks being further from the settlements. There was more regular human disturbance (occasional sand mining, waste deposition) in mines near villages, while mines being further away were rarely frequented by people, whose presence could disturb the birds.

Ragats (2001) found in the Little Plain, that very small amount of birds bred in banks with northern and western exposure, which were available for birds in a high proportion. This could be mainly because these banks were perpendicular to the typical and common north-northwest direction of the wind. As a consequence, the cool air flowed directly into the nesting-holes and they were very dry and cold. The cool and windy microclimate of the tunnels could adversely affect the development of the nestlings. According to the studies conducted in West Hungary (Gyurácz \& Szanyi 1994b, Ragats 2001) the more rapidly warming southern exposure parts of the banks provided better temperature for the development of nestlings, so most nestings have been detected in the southern exposure parts of banks. There were just a few breeding pairs in the sections facing directly to south, which can be explained by the overheating. So the southwest, southeast, west and east facing 
banks provided really favourable climate to the birds and it is probably not a coincidence that most of the nesting pairs settled down in these parts banks. According to Gyovai's (1993) South Great Plain, Nagy's (1996) Upper Tisza, Lajtmann's (1998) Central Hungary and Batta and Misik's (2008) North Hungary investigations, no clear effect of the exposure of the banks can be identified on the breeding site choice of the European Bee-eaters.

\section{Feeding ecology}

The European Bee-eater is known as 'beekeeper bird' because of catching flying insects (Lepidoptera, Heteroptera, Orthoptera, Odonata, Coleoptera, Diptera), and they readily hunt Hymenoptera, within that group particularly stinging insects such as bees (Apidae) and wasps (Vespidae). Flying or sitting bee-eaters can see bees from long distance and after a shorter or longer chase they can catch them (Fry 1984). The feeding ecology of the European Bee-eater and the harm suffered by apiaries were studied relatively intensely in Hungary (Bendiák 1998, Fehér 1995, 1999, Sík et al. 1955, Szederkényi et al. 1955, Gyovai 1993, Laczik 1996, Rékási \& Haraszthy 2005, Batta \& Misik 2008). Fry's summary article (1983) published in an apiary journal was outstanding among many foreign publications, since it summarised the results of studies executed in different countries, and discussed its economic aspects, as well. Those insects were clearly dominant in the diet of bee-eaters, which could be found in the largest numbers at that time in the area. This view was supported by Costa's (1991) Portuguese investigations, in which the food composition of the feeding birds near and further an apiary were compared. He showed that the ratio of honeybees in the diet of the feeding birds near an apiary was significantly higher (almost $50 \%$ ) than in the diet of those hunting further from an apiary (about 10\%). According to a Hungarian study (Fuisz et al. 2013) the prey composition also showed marked differences between the individual colonies. Bee-eaters breeding near the Danube shore consumed a large quantity of dragonflies, while at the colony, surrounded by agricultural fields and meadows, orthopterans and coleopterans were consumed in similar quantity as dragonflies.

The economic impact on apiculture by European Bee-eaters was usually negligible, but losses of drones were locally important (Galeotti \& Inglisa 2001). Fintha 1968 showed that the composition of the bee-eaters' diet was strongly influenced by weather, because insects usually do not fly under cool and windy conditions. But bees flew in large numbers under these circumstances, therefore their ratio in the bee-eaters's diet also increased. Laczik (1996) found that the food composition of the Bee-eaters varied according to the time of the day. The birds' food composition followed the daily activity of different insect groups, which also proved that the birds always caught the preys that were available in the largest quantities (Gyovai 1993). According to the same study, the birds preferred the large prey items, so they chose the relatively larger sized bumble bees (Bombus spp.) among the bees. According to a Southern Hungarian study (Horváth et al. 1992) the parent birds often brought more food to the nest than the chicks could consume at once. The surplus food was piled up in the entrance of the nesting-holes, but its amount decreased over time. Parents needed a few days to deliver sufficient amount of food required by chicks. 
During the digging and incubation periods, the adults' movements were scarce and concentrated during the morning, but in the chick-rearing stage they flew intensively from the early morning to noon. The start of daily activity and the fly rate of the adults to the nests were strongly correlated to air temperature (Inglisa \& Galeotti 1993).

A huge array of prey choice of the European Bee-eater was recorded by various European studies, thus it became evident, it is not exclusively consume Western Honeybees, as previously thought. Variations in diet mainly reflect temporal, spatial and ecological dynamics in insect fauna (Fry 1983).

\section{Migration and dispersion}

Each European population are obligate long-distance migrants. The West and South European breeding birds over-winter in the savannahs stretching from Senegal to Nigeria, the Central and Eastern European ones over-winter in Central and East Africa, especially in the Congo Basin. The European populations can be characterised by broadfront overland migration and they migrate through Gibraltar, over the Apennine Peninsula and Sicilian channel, as well as over Cyprus and Greece, towards Israel in the autumn. The autumn migration of the European Bee-eaters starts in mid-August, peaks in September and delays early October in Europe. The first specimens reach Africa in mid-September (Cramp 1998).

Birds predominantly utilise the Central (i.e. via Sicily) and Eastern (i.e. via Israel and Greece) Eurasian flyways during spring migration. Bee-eaters are gregarious diurnal migrants presumably crossing large barriers like the Sahara and the Arabian deserts with non-stop flight. Some nocturnal migration also occurs (Cramp 1998, Snow \& Perrins 1998). Yosef (2010) observed a previously unreported thermoregulatory behaviour of migratory European Bee-eaters: diving into the sea and salt ponds with high levels of salinity in Israel. Spring migration begins in early March and the first birds arrive in mid-April in Europe, but some of them are already returning in May. The experienced adults with better condition stop fewer times than juveniles during the spring migration, and returned to their breeding sites before the juveniles (Yosef et al. 2006). Sapir et al. (2011) suggest that Bee-eaters and other small birds soar and glide during migration and dispersal, and possibly in other stages in their annual cycle too, because it may entail a low energy cost of transport. Spring migrants often overshoot under anticyclonic weather condition, and regularly reach Northwest Europe and exceptionally even nest there (Cramp 1998).

Only three Hungarian ringed birds were recovered abroad, all of them were adults ringed in the breeding season and all were shot in Greece (Figure 4). On this basis, we can assume that the main autumn migratory direction of the Hungarian birds was SE. The longest distance covered was $1207 \mathrm{~km}$ by a bird ringed at Lake Velence. A bird ringed in Slovakia was found dead and another one was recaptured in Hungary. It is likely that only the Bee-eaters breeding in the Carpathian Basin pass across Hungary and their wintering sites are still unknown. The majority of nesting birds arrive back until the second half of May from their wintering areas according to the monthly distribution of ringing data. In Hungary, the autumn migration begins in August, peaks in the third decade of the month. By the end of September, the last Bee-eater leaves Hungary (Gyurácz 2009). 


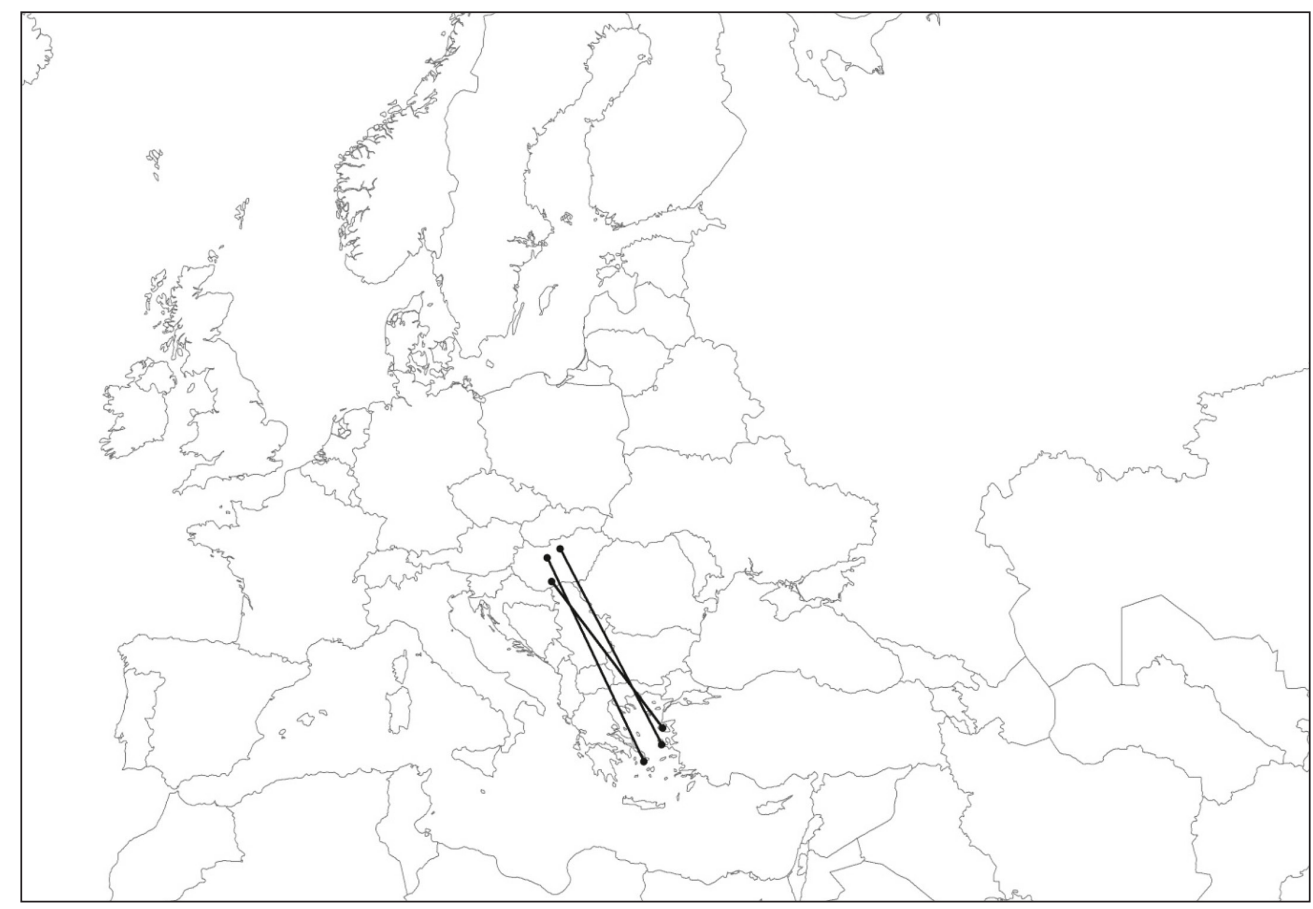

Figure 4. Recoveries of European Bee-eaters ringed in Hungary

4. ábra Magyarországi gyűrűzésű gyurgyalagok visszafogása Európában

Three percent of the Bee-eaters ringed in Hungary were recovered within five kilometres away from their ringing sites. Furthermore, 34.0 and 27.7 percent of the adults returned to their former nesting place, but the return rates of the first year females and males were only 0.4 and 5.9 percent (Lessels \& Krebs 1989, Gyovai 1993). This was supposedly because of the relatively high natal dispersion and average 67\% mortality rate of juveniles. The intercolony dispersal is known to be very little. Twelve polymorphic microsatellite markers have been developed for the European Bee-eater, which will provide insight into the kin selection and the importance of emigration and immigration in the dynamics in colony size (Dasmahapatra et al. 2004). The oldest bird ringed in Hungary lived for at least five years. None out of the nestlings ringed in
Hungary has been recovered three years after they were caught (Gyurácz 2009).

\section{Intraspecific relationships}

The European Bee-eater is typically a social bird in breeding, migration and wintering, as well. Migrating flocks can contain more than hundreds of individuals. The European Bee-eater is generally a monogamous species and most of the couples remain together throughout their lives. After the death of its pair, the surviving bird chooses a new companion. Males and females are paired according to the courtship ceremony during wintering and arrive back together to the breeding sites (Cramp 1998). The juvenile males are often paired with older females (Gyovai 1993). The proportion of males is usually higher than 
females in breeding colonies, so the males whose breeding attempts have failed earlier in the year become helpers and take part in fledglings care of the other couples. In Hungary, helpers occurred at one out of 8 pairs (Cramp 1998). A study carried out by Václav (2000) indicates that male helpers took part both in incubation and feeding of the chicks, and interestingly one of them deserted the pair it started to help and shared parental care at another pair. Multilocus minisatellite markers have previously been applied to estimate the connection of helpers to the breeding pair. Various aspects of the ecology role and evolutionary importance of the common European Bee-eater helpers have been discussed by Dyer and Demeter (1981), Lessels and Avery (1989), Jones et al. (1991), Lessels (1991), Lessels et al. (1994) and Václav (2000). During egg laying the male hunts for insects and gives the larger preys to the female, smaller ones consumed by itself (Avery et al. 1988). The European Bee-eater has a typical asynchronous hatching, but all the chicks hatch in 1-2 days. Both parents are involved in the incubation and rearing of chicks (Lessels \& Avery 1989). Feeding was carried out in different times of the day by the parents. In most of the cases, they fed in the morning and at noon (Fintha 1968, Gyovai 1993, Laczik 1996). The parents fed more if they had more and older nestlings (Dyer \& Demeter 1981). The adult bee-eaters rest, sunbathe and preen in small group on the branches between the two feeding.

\section{Interspecific relationships}

Besides feeding the European Bee-eater has other types of interspecific relationships, as well. It is not a popular prey item of most other animals, but it can occasionally be hunted by birds of prey and mammals. According to the Romanian monitoring of Petrescu and Adam (2001), the most common Bee-eater predators can be the following species; reptiles: Caspian Whipsnake (Coluber caspius), birds: Common Kestrel (Falco tinnunculus), Eurasian Hobby (Falco subbuteo), Short-toed Snake Eagle (Circaetus gallicus), Booted Eagle (Aquila pennata), Northern Goshawk (Accipiter gentilis), Common Buzzard (Buteo buteo), Longeared Owl (Asio otus), Little Owl (Athene noctua), mammals: Least Weasel (Mustela nivalis). The one-day-old chicks were often attacked by ground beetles (Carabidae). The Bee-eaters use three different defense modes against predators. They warn each other and other species by alarm-sound, expel the predator together or hide in tree branches.

Nosema ceranae is a Microsporidia recently described as a parasite in honeybees so the regurgitated pellets of Euroepean Bee-eaters can be fomites of infective spores (Higes et al. 2008).

From the louse (Phthiraptera), three species (Brueelia apiastri, Meromenopon meropis, Meropoecus meropis) are found on European Bee-eaters (Petrescu \& Adam 2001). The lice mainly parasitise the adults and the ratio of infected chicks was substantially smaller than of the adults (Darolova et al. 2001). Karáth et al. (2013) showed that male European Bee-eaters tend to have higher intensity of Meropoecus infestation than females. The 2-3 mm sized Carnus hemapterus is a common blood sucking fly (Diptera) species that also occurs on the nestlings of European Bee-eaters, whose larvae is saprophagous and develops in the nest of birds (Petrescu \& Adam 2000). Two louse flies (Hippoboscidae) species (Ornithomyia avicularia, Pseodolychia canaren- 
sis) were showed from the European Bee-eater in Slovakia (Krištofík et al. 1996). A new mite species (Acarophenax merops) was described from the European Bee-eater (Rakha $\&$ Kandeel 1983). An internal parasitic tapeworm (Cestoda) species was found in the European Bee-eater, as well (Gyovai 1984).

The nesting-holes of the bee-eaters provide relatively good protection against nest predators and extreme weather, so the following species also utilise their nestholes for nesting: Common Kestrel, Little Owl, Common Swift (Apus apus), European Roller (Coracius garrulus), Eurasian Tree Sparrow (Passer montanus), House Sparrow (Passer domesticus), Common Starling (Sturnus vulgaris). In South Africa, the presence of Pied Starlings (Spreo bicolor) within breeding colonies provides a direct benefit to the bee-eaters because of their aggressive and successful attacks on potential nest predators. It can be a potential cost to the bee-eaters, since the starlings occupy their nesting-holes from previous seasons and occasionally oust bee-eaters from active nests (Török 1999).

\section{Threatening factors}

The national monitoring and protection project for European Bee-eater revealed the following threats for the birds and their habitat (Haraszthy 2003):

The human disturbance of breeding sites (e.g. camping, shooting, mining etc.) may prevent the settling of birds in suitable breeding places. The most common destroying method of the nests is plugging the entrance of the breeding-holes with cloth, tree branches etc., often when the parent birds are there. In such cases, the chicks always, the parents occasionally die. Sometimes people put burning sulfur sticks in the breeding-holes and the smoke also kills the birds (Nagy 2000). The breeding banks were often deliberately destroyed, however it occurs mostly due to not intentional destruction against the bee-eaters, but negligence. The nests are usually destroyed because of stripping the banks for its sand material. It also happens that sand-mines earlier used for nesting are filled with municipal waste or slurry, thereby destroying the breeding sites. The small-scale and less steep banks overgrow with vegetation in a few years and bushes grow up in front of the banks, that prevents the birds to enter or leave (Urbán et al. 2013). It causes the cessation of breeding sites primarily in the enclosed sand-mines. The Red Fox (Vulpes vulpes) and European Badger (Meles meles) often dig out the eggs or chiks.

The vertical banks of mines are made to slope due to recultivation of enclosed sandmines required by law, so they become unsuitable for nesting. The most frequent factors endangering nesting include human disturbance (e.g. mining, shooting, tourism) $(27-30 \%)$, weed invasion on vertical banks $(24-25 \%)$ as well as the erosion-collapse of vertical banks (17-21\%) in Hungary (Gyurácz et al. 2004, Batta \& Misik 2008).

The poachers often shoot the bee-eaters to make mounted bird preparations. In recent years, it happened more frequently that bee-eaters have been found in boot of Italian hunters' cars. This is a higher risk due to its magnitude than the hunting for preparation. Birds were often became victims of roadkills. The European Bee-eaters feeding in a stopover sit somtimes fly to the cars during autumn migration.

The concentrations of pesticides used in agriculture may be high in the main preys of bee-eaters therefore the possibility of in- 
direct poisoning cannot be excluded. The usage of the contact insecticid can be particularly dangerous. Some bee-eater populations bred at a metal mining site were endangered by arsenic and metal stress (aluminium, cadmium, cobalt, chromium, iron) according to feather and regurgitated pellet analyses (Lopes et al. 2010).

\section{Legal and practical protection}

The following activities and conservation measures are necessary for the stabilisation of the current breeding population and maintenance of largest colonies (Gyurácz 1998b, Haraszthy 2003).

The breeding colonies of more than 50 pairs must be declared protected by the competent authorities. More suitable vertical banks for breeding - at least 6 meter long and 1 meter high - should be created and left untouched in the breeding seasons in sand areas by modification of the legislation for the recultivation of mines. It is necessary to regulate the installation of apiaries so that they can be far enough away from the breeding colonies and the stopover sites to avoid conflicts with beekeepers. The specially protected status of European Bee-eater should be maintained for the prevention of human destruction and disturbance.

The maintenance of loess banks is necessary and the re-growth of vegetation should be prevented. In some regions of the country, there are not enough suitable breeding banks, so the nesting of the European Bee-eaters can be supported by the creation of artificial nesting sites in these areas. The artificial banks must be established preferably in areas owned by local councils, national parks or foundations. Each year, no later than the second half of April, the bank walls should be reshaped by the removal of the disturbing roots and plants with the upper 5-10 cm layer of sand. The fresh bank surface attracts the bee-eaters, while the birds leave the old, crumbling ones (Urbán et al. 2013). Foxes and badgers should be kept away from the breeding colonies by the co-operation with the hunting authorities. The conservation authority should do everything in order to prevent the shooting of bee-eaters and the destruction of their nest sites. The shooting of bee-eaters and plugging of their nets-holes for any reason should be avoided by effective awareness raising activities. In order to protect the bee-eaters' nesting in freshly created banks, it is necessary to convince owners to not touch the sand- and loess bank in the breeding season, and it is facilitated by presenting them with well-illustrated information and materials.

The monitoring of the breeding population and sites that began in 1992 should be continued. The effective methods of the prevention of the damage caused by bee-eaters and alert procedures used around the apiaries need to be continued. The impact of chemical plant protection on bee-eaters is necessary to be investigated, and management of crops around breeding colonies should be performed with great care.

The destruction of bee-eater colonies and persecution of birds largely happens due to negligence, but sometimes intentional human activities also harm the species. In order to change this status quo, extensive propaganda activities and campaigns are needed to protect the bee-eaters. Specific information must be disclosed to the beekeepers, and it should be clear for them, that their licence will be suspended if they are either unwilling to co-operate or to comply with the nature conservation act. Co-opera- 
ting individuals and organisations should be assisted by the possibility of positive discrimination, for example compensation, facilitating access to markets or otherwise. All ways of the media (printed, TV, radio, online) should be involved in the awareness raising activities about the European Bee-eater. The involvement of mine owners, operators, mine inspectorates, national parks, ranger officers, field officers and civilian wardens into the implementation of the practical conservation works is an important task.

The safe and non-disruptive presentation of the bee-eater breeding colonies should be

\section{References}

Aizenpreisz, L. 1929. A gyurgyalag Merops apiaster fészkelése Véménden [Bee-eater Merops apiaster breeding in Véménd]. - Aquila 34-35: 376 . (in Hungarian)

Alexay, Z. 1997. Változó Szigetköz [Changing Szigetköz]. - Hazánk Könyvkiadó, Győr p. 64. (in Hungarian)

Ar, A. \& Piontkewitz, Y. 1992. Nest ventilation explains gas composition in the nest-chamber of the European Bee-eater. - Respiration Physiology 87: 407-418.

Avery, M. I., Krebs, J. R. \& Houston, A. I. 1988. Economics of courtship-feeding in the European Bee-eater (Merops apiaster). - Behaviour Ecology and Sociobiology 23: 61-67.

Bagdi, A. 1999a Gyurgyalag (Merops apiaster) és partifecske (Riparia riparia) állományfelmérő program 1997-1998 [Survey of European Bee-eater (Merops apiaster) and Sand Martin (Riparia riparia) populations 1997-1998]. - Hír-Körlevél (Magyar Madártani és Természetvédelmi Egyesület Komárom-Esztergom megyei Helyi Csoport) 1: 2-3. (in Hungarian)

Bagdi, A. 1999b Gyurgyalag (Merops apiaster) és partifecske (Riparia riparia) állományfelmérő program megyei eredményei, 1999 [Results of survey of European Bee-eater (Merops apiaster) and Sand Martin (Riparia riparia) populations in the county Komárom-Esztergom, 1999]. - Hír-Körlevél (Magyar Madártani és Természetvédelmi Egyesület Komárom-Esztergom megyei Helyi Csoport) 4: 2. (in Hungarian) ensured to the general public and the neighbourhood schools in order to better understand how we can contribute to the protection of the species.

\section{Acknowledgements}

We wish to express our gratitude to all those members of BirdLife Hungary, MME Monitoring Center as well as the staff of National Park Directorates who helped us in our field works. We are grateful to T. Csörgő and two anonymous reviewers for helpful comments on the manuscript.

Bagdi, A. 2013. Gyurgyalag - az év madara [European Bee-eater - 'The Bird of the Year']. - Madártávlat 20(1): 4-6. (in Hungarian)

Báldi, A., Csorba, G. \& Korsós, Z. 2001. Setting priorities for the conservation of terrestrial vertebrates in Hungary. - Biodiversity and Conservation 10: 1283-1296.

Bali, J. 1982. Két gyurgyalag (Merops apiaster) telep Veszprém megyében [Two colonies of European Bee-eater (Merops apiaster) are in the county Veszprém]. - Madártani Tájékoztató (január-március): 40. (in Hungarian)

Bankovics, A. 2000. Gyurgyalag Merops apiaster [European Bee-eater Merops apiaster] - In: Haraszthy, L. (szerk.) Magyarország madarai, 2. javított kiadás. - Mezőgazda Kiadó, Budapest pp. 232233. (in Hungarian)

Bankovics, A., Győry, J. \& Sterbetz, I. 1989. Gyurgyalag Merops apiaster Linnaeus, 1758 [European Bee-eater Merops apiaster Linnaeus, 1758]. - In: Rakonczay, Z. (szerk.) Vörös Könyv. A Magyarországon kipusztult és veszélyeztetett növény- és állatfajok [Extinct and endangered plant and animal species in Hungary]. - Akadémiai Kiadó, Budapest pp. 140-142. (in Hungarian)

Barta, Z. 1998. Újabb adatok a Balaton-felvidék északkeleti részének madárvilágához I. [Further data about the bird fauna of the north-eastern part of the Balaton highlands I.] - A Bakonyi Természettudományi Múzeum Közleményei 13: 149 198. (in Hungarian with English Summary) 
Batta, G. \& Misik, T. 2008. A Hevesi homokhát gyurgyalag-telepeinek komplex felmérése [Bee-eater colonies at the Heves sand-hill area]. - Acta Academiae Paedagogicae Agriensis, Sectio Pericemonologica 35: 37-46. (in Hungarian with English Summary)

Bécsy, L. 1966. Gyurgyalagok fürdése a Dunában [Bee-eaters bathing in the Danube]. - Aquila 7172: 232-233. (in Hungarian with English Summary)

Bendiák, I. 1998. Gyurgyalag, gyurgyalag - miért vagy te gyurgyalag? [Bee-eater, Bee-eater why are you Bee-eater?]. - Méhészújság 11(7): 32. (in Hungarian)

Beretzk, P. 1959. Méhészmadár fészkelése a Tisza és Maros partfalaiban [Breeding of the Bee-eater in the clay-walls on the shores of the rivers Tisza and Maros]. - Aquila 65: 289. (in Hungarian with English Summary)

BirdLife International 2004. Birds in Europe: population estimates, trends and conservation status. Cambridge, UK: BirdLife International (BirdLife Conservation Series No. 12).

BirdLife International 2013. Species factsheet: Merops apiaster. Downloaded from http://www.birdlife. org on $06 / 12 / 2013$.

Bókai, B. 1957. Gyurgyalag előfordulása a Pilisben [Appearance of the Eureopean Bee-eater in the Pilis-mountains]. - Aquila 63-64: 290. (in Hungarian with English Summary)

Breuer, Gy. 1950. Gyurgyalagok Sopron megyei fészkelése [Bee-eater breeding in the county Sopron ]. - Aquila 51-54: 167. (in Hungarian with English Summary)

Buschmann, F. \& Mester, I.-né 1988. Gyurgyalag (Merops apiaster) ,invázió” a hajtai természetvédelmi területen ['Invasion' of the Bee-eater in the nature reserve of Hajta]. - Calandrella 2(2): 110. (in Hungarian)

Casas-Criville, A. F. \& Valera, F. 2005. The European Bee-eater (Merops apiaster) as an ecosystem engineer in arid environments. - Journal of Arid Environments 60: 227-238. doi:10.1016/j.jaridenv.2004.03.012

Costa, L. T. 1991. Apiculture and the diet of breeding European Bee-eater Merops apiaster. - Airo 2(2): 34-42.

Cramp, S. 1998. The Complete Birds of the Western Palearctic. - CD-ROM, Oxford University Press, Incorporated, Oxford

Csapó, D. 1918. A gyurgyalagról Merops apiaster L. [About Bee-eater Merops apiaster L.] - Aquila 24: 277-278. (in Hungarian with German Summary)

Darolova, A., Hoi, H., Kristofik, J. \& Hoi, C. 2001. Horizontal and vertical ectoparasite transmission of three species of malophaga, and individual variation in European Bee-eaters (Merops apiaster). - Journal of Parasitology 87: 256-262.

Dasmahapatra, K. K., Lessel, C. M., Mateman, A. C. \& Amos, W. 2004. Microsatellite loci in the European Bee-eater, Merops apiaster. - Molecular Ecology Notes 4: 500-502. doi:10.1111/j.14718286.2004.00726.x

Dickinson, E. C. (ed.) 2003. The Howard and Moore complete checklist of the birds of the World. Princeton University Press, Princeton, NJ.

Dickinson, E. C. \& Remsen, Jr. E. C. (eds.) 2013. The Howard and Moore complete checklist of the birds of the World. $-4^{\text {th }}$ Edition, Vol. 1. Aves Press, Eastbourne, U.K.

Dorning, H. 1949. A gyurgyalag [The Bee-eater]. Természet és Technika 108(6): 368-369. (in Hungarian)

Dorning, H. 1955. A gyurgyalag költése Csömörön és Nagy-Budapest területén [Bee-eater nesting in Csömör and Budapest]. - Aquila 59-62: 387-388. (in Hungarian with English Summary)

Dvorak, M., Ranner, A. \& Berg, H-M. 1993. Atlas der Brutvögel Österreichs. Ergebnisse der Brutvogelkartierung 1981-1985 der Österreichischen Gesellschaft für Vogelkunde [Atlas of breeding birds in Austria. Results of the breeding bird census 1981-1995 the Austrian Society for Ornithology]. - Bundesministerium für Umwelt. Jugend und Familie, Wien (in German)

Dyer, M. \& Demeter, A. 1981. Notes on the provisioning rates of Bee-eaters (Merops apiaster) in North-East Hungary. - Aquila 88: 87-90.

Farkas, T. 1967. Ornithogeographie Ungarns [Avian geography of Hungary]. - Duncker \& Humblot, Berlin (in German)

Farkas, R., Boldogh, S., Szentgyörgyi, P. \& Bartha, Cs. 2003. A gyurgyalag (Merops apiaster L., 1758) állományának felmérése és védelme Észak-Magyarországon [Research on Bee-eater (Merops apiaster L., 1758) population and its conservation in North Hungary]. - ANP Füzetek II. 97-106. (in Hungarian with English Summary)

Fehér, P. 1995. A gyurgyalagról [About the Bee-eater]. - Méhészújság 8(11): 13. (in Hungarian)

Fehér, P. 1999. Gyurgyalag (Merops apiaster Linné) [European Bee-eater Merops apiaster Linné]. Méhészet 47(4): 11. (in Hungarian)

Fintha, I. 1968. Megfigyelések a Szamos menti gyurgyalagok (Merops apiaster) fészkelési viszonyairól és táplálkozásáról [Observation about nesting and feeding of European Bee-eaters Merops apiaster breeding along the river Szamos]. - Aquila 75: 93-109. (in Hungarian with German Summary) 
Fintha, I. 1969. A Szamos hazai szakaszát kísérő meredek partfalak madarai [Birds of vertical banks of the river Szamos]. - A Nyíregyházi Jósa András Múzeum Évkönyve 11: 273-279. (in Hungarian with German Summary)

Fry, C. H. 1983. Honeybee predation by Bee-eaters, with economic considerations. - Bee World 64(2): 65-78.

Fry, C. H. 1984. The Bee-eaters. - T \& AD Poyser, Calton

Fry, C. H. 1994. Bee-eater Merops apiaster. - In: Tucker, G. M. \& Heath, M. F. (comp.): Birds in Europe. Their Conservation Status. - BirdLife International, Cambridge pp. 338-339.

Fuisz, T. I., Vas, Z., Túri, K. \& Körösi, Á. 2013. Photographic survey of the prey-choice of European Bee-eaters (Merops apiaster Linnaeus, 1758) in Hungary at three colonies. - Ornis Hungarica 21(2):

Galeotti, P. \& Inglisa, M. 2001. Estimating predation impact on honeybees Apis mellifera L. by European Bee-eaters Merops apiaster L. - Revue d Ecologie (Terre Vie) 56: 373-388.

Glutz von Blotzheim, U. N. \& Bauer, K. M. (Bearb.) 1980. Handbuch der Vögel Mitteleuropas. Band 9. Columbiformes - Piciformes. [Handbook of the birds of Central Europe]. - Akademische Verlagsgesellschaft, Wiesbaden

Gönye, D. 1935. Gyurgyalag Kétyen [The European Bee-eater in Kéty]. - Aquila 38-41: 354. (in Hungarian with German Summary)

Greschik, J. 1938. A gyurgyalag késői érkezése 1936. tavaszán [The late arrival of European Bee-eater in the spring of 1936]. - Kócsag 9-11: 94. (in Hungarian with German Summary)

Gyovai, F. 1979. Gyurgyalag- és partifecske-telepek állománybecslése Hódmezővásárhely határában [Population estimate of European Bee-eater and Sand Martin colinies near Hódmezővásárhely]. Madártani Tájékoztató (október-december): 3031. (in Hungarian)

Gyovai, F. 1984. Gyurgyalag (Merops apiaster) és jégmadár (Alcedo atthis) féregparazitái [Parasitic worms of European Bee-eater (Merops apiaster) and Common Kingfisher (Alcedo atthis)]. - Madártani Tájékoztató (október-december): 224 225. (in Hungarian)

Gyovai, F. 1993. Egy dél-alföldi gyurgyalag (Merops apiaster) populáció kor-struktúrája, költés- és táplálkozásvizsgálata [Age structure, breding and foraging biology of Bee-eater (Merops apiaster) in Hungary]. - Ornis Hungarica 3(1): 23-32. (in Hungarian with English Summary)

Gyurácz, J. 1998a Országos gyurgyalagvédelmi program 1997-1998. [Hungarian European Bee-ea- ter monitoring and conservation program 19971998]. - Madártávlat 5(6): 8. (in Hungarian)

Gyurácz, J. 1998b Az „Országos gyurgyalagvédelmi program" védelmi javaslatai [Conservation proposals of the 'Hungarian European Bee-eater monitoring and conservation program']. - Cinege 3 : 6-7. (in Hungarian)

Gyurácz, J. 1999. A gyurgyalag (Merops apiaster) költőtelepei Vas megyében [Nesting colonies of the Common Bee-eater (Merops apiaster) in Vas county]. - Vasi Szemle 53(1): 45-52. (in Hungarian with English and German Summary)

Gyurácz, J. 2000. A költő gyurgyalagok (Merops apiaster) állományának felmérése és védelme Vas megyében (2000) [Survey and conservation of the breeding population of European Bee-eater in county Vas (2000)]. - Cinege 5: 11-12. (in Hungarian)

Gyurácz, J. 2009. Gyurgyalag Merops apiaster Linnaeus, 1758 [European Bee-eater Merops apiaster Linnaeus, 1758]. - In: Csörgö, T., Karcza, Zs., Halmos, G., Magyar, G., Gyurácz, J., Szép, T., Schmidt, A. \& Schmidt, E. (szerk.) Magyar madárvonulási atlasz [Hungarian bird migration atlas]. - Kossuth Kiadó, Budapest pp. 377-380. (in Hungarian with English Summary)

Gyurácz, J. 2012. Gyurgyalag Merops apiaster Linnaeus, 1758. [European Bee-eater Merops apiaster Linnaeus, 1758]. - In: Faragó, S. (szerk.) Nyugat-Magyarország fészkelő madarainak elterjedési atlasza [The atlas of West Hungarian breeding birds]. - Nyugat-magyarországi Egyetem Kiadó, Sopron p. 132. (in Hungarian)

Gyurácz, J. \& Nagy, K. 1999. A gyurgyalag (Merops apiaster) fészkelő állományának eloszlása és természetvédelmi helyzete Magyarországon [Distribution and nature conservation status of European Bee-eater (Merops apiaster) in Hungary]. - Magyar Madártani és Természetvédelmi Egyesület 5. Tudományos Ülés, Budapest, Csillebérc, poszter: 7. (in Hungarian)

Gyurácz, J. \& Nagy, K. 2000. A gyurgyalag (Merops apiaster) fészkelő állományának felmérése és védelmi helyzete Magyarországon (1997-1999) [Survey and nature protection status of European Bee-eater (Merops apiaster) in Hungary (19971999)]. - Szünzoológiai Szimpózium, Budapest, Összefoglalás: 13. (in Hungarian)

Gyurácz, J. \& Nagy, K. 2001. Assesment of the Bee-eater Merops apiaster nesting population and its protection status in Hungary, 1997-2000. - Bird Numbers 2001. Monitoring for nature conservation. $15^{\text {th }}$ International Conference of the EBCC, Nyíregyháza-Hungary Abstracts: 99. 
Gyurácz, J., Nagy, K., Bagdi, A., Hadarics, T. \& Ragats, Zs. 2004. A gyurgyalag (Merops apiaster) monitorozása és védelmi helyzete Magyarországon, 1997-2001. [Protection status and monitoring of the Bee-eater (Merops apiaster) in Hungary, 1997-2001]. - Természetvédelmi Közlemények 11: 481-491. (in Hungarian with English Summary)

Gyurácz, J. \& Szanyi, K. 1994a Az 1991-93. évi gyurgyalag (Merops apiaster L., 1758) felmérés eredményei Vas megyében [Results of the 1991-93 annual European Bee-eater survey in county Vas]. - Szélkiáltó 8: 13-14. (in Hungarian with German Summary)

Gyurácz, J. \& Szanyi, K. 1994b A Vas megyében költő gyurgyalag (Merops apiaster) állomány eloszlása és egyedszáma [Number and distribution of Bee-eater (Merops apiaster) population breeding in sand-pits in county Vas]. - Aquila 101: 123132. (in Hungarian with English Summary)

Halmosi, J. 1978. Gyurgyalagok (Merops apiaster) megtelepedése a székesfehérvári homokbányáknál [Nesting of Bee-eater (Merops apiaster) in sand-pits near Székesfehérvár]. - Madártani Tájékoztató (szeptember-október): 18. (in Hungarian)

Haraszthy, L. (szerk.) 2003. Veszélyeztetett madarak fajvédelmi tervei [Species conservation plans of the threatend birds]. - Magyar Madártani és Természetvédelmi Egyesület, Budapest (in Hungarian)

Heath, M., Borggreve, C. \& Peet, N. (comp.) 2000. European bird populations. Extimates and trends. - BirdLife International, Cambridge

Heneberg, P. \& Šimeček, K. 2004. Nesting of European Bee-eaters (Merops apiaster) in Central Europe depends on the soil characteristics of nest sites. Biologia 59: 205-211.

Higes, M., Martín-Hernández, R., Garrido-Bailón, E., Botías, C., García-Palencia, P. \& Meana, A. 2008. Regurgitated pellets of Merops apiaster as fomites of infective Nosema ceranae (Microsporidia) spores. - Environmental Microbiology 10(5): 1374-1379. doi:10.1111/j.14622920.2007.01548.x

Horváth, F. 1980. Gyurgyalag (Merops apiaster) újabb telepe [New colony of European Bee-eater ( $\mathrm{Me}$ rops apiaster)]. - Madártani Tájékoztató (januármárcius): 21-22. (in Hungarian)

Horváth, G., Fischer, M. H. \& Székely, T. 1992. The delivery of surplus prey to the nest by a pair of Bee-eaters (Merops apiaster). - Ornis Hungarica 2(1): 11-16.

Inglisa, M. \& Galeotti, P. 1993. Daily activity at nests of the European Bee-eaters (Merops apiaster). Ethology Ecology \& Evolution 5(1): 107-114. doi: $10.1080 / 08927014.1993 .9523118$
Jáky, K. 1990. Gyurgyalagok (Merops apiaster) a Gödöllői-dombságon [European Bee-eaters (Merops apiaster) are in Gödöllő Hills]. - Madártani Tájékoztató 1990: 55-56. (in Hungarian)

Jánoska, F. 1993. Etológiai vizsgálatok gyurgyalag (Merops apiaster L.) költőtelepen [Etology study in breeding colony of European Bee-eaters (Merops apiaster L.)]. - Szélkiáltó 5: 4-6. (in Hungarian with German Summary)

Jones, C. S., Lessells, C. M. \& Krebs, J. R. 1991. Helpers at the nest in European Bee-eaters (Merops apiaster): a genetic analysis. - In: Burke, T., Dolf, A., Jeffreys, A. J. \& Wolff, R. (eds.) DNA fingerprinting: approaches and applications. - Birkhauser Verlag, Basel pp. 169-192.

Kagyerják, P. 1983. Gyurgyalag (Merops apiaster) vonulási adatok Balassagyarmat környékéről (1982) [Migration data of European Bee-eater (Merops apiaster) from Balassagyarmat area (1982)]. - Madártani Tájékoztató (január-június): 36. (in Hungarian)

Karáth, K., Fuisz, T. I. \& Vas, Z. 2013. Louse (Insecta: Phthiraptera) infestations of European Bee-eaters (Merops apiaster Linnaeus, 1758) at Albertirsa, Hungary. - Ornis Hungarica 21(1):

Kállay, Gy. 1978. Beszámoló a MME Választmányi üléséröl [Report on the meeting of MME Committee]. - Madártani Tájékoztató (november-december): 1-4. (in Hungarian)

Kárpáti, L. 1989. Gyurgyalagok (Merops apiaster) a Fertő mentén [European Bee-eaters (Merops apiaster) are in Fertő area]. - Madártani Tájékoztató 1-2: 82-83. (in Hungarian)

Keller, O. 1949. Érdekességek és változások Keszthely és környékének madárfaunájában [Curiosities and changes in the bird fauna of Keszthely and surrounding area]. - Természet és Technika 98(8): 496-497. (in Hungarian)

Kerényi, Z. \& Ivók, E. 2013. Nesting habits of the European Bee-eater (Merops apiaster L.) in the Gödöllő Hills. - Ornis Hungarica 21(2):

Kertész, L. 1986. Gyurgyalag (Merops apiaster) és partifecske (Riparia riparia) fészkelöhelyek felmérése 1985-ben a Gödöllöi dombok - Tápiósáp területén [Survey of the nesting sites of European Bee-eater (Merops apiaster) and Sand Martin (Riparia riparia) at the area of Gödöllö Hills and Tápisáp in 1985]. - Madártani Tájékoztató (januármárcius): 36-39. (in Hungarian)

Kertész, L. 1991a Gyurgyalag (Merops apiaster), partifecske (Riparia riparia) és hantmadár (Oenanthe oenanthe) fészkelőpárok felmérése a Gödöllöi-dombság térségében lévő homokbányákban [Survey of the nesting pairs of European Bee-eater (Merops apiaster), Sand Martin (Riparia ripa- 
ria) and Northern Wheatear (Oenanthe oenanthe) in sand-pits of Gödöllő Hills]. - Madártani Tájékoztató 1-2: 9-10. (in Hungarian)

Kertész, L. 1991b A gyurgyalag (Merops apiaster) és a partifecske (Riparia riparia) fészkelőállományának változásai a Gödöllői-dombság térségében lévő homokbányákban [Changes of European Bee-eater (Merops apiaster), Sand Martin (Riparia riparia) breeding population in sand-pits of Gödöllő Hills]. - Madártani Tájékoztató 3-4: 1617. (in Hungarian)

Keve, A. 1978. Adatok a Tapolcai-medence madárvilágához [Data about bird fauna of Tapolca basin]. - A Veszprém Megyei Múzeumok Közleményei (Természettudomány) 13: 61-75. (in Hungarian with German Summary)

Keve, A. 1981. Madártani adatok a Déli-Bakonyból, valamint a Bakonyaljáról [Ornithological data in South Bakony and Bakonyalja]. - A Veszprém Megyei Múzeumok Közleményei (Természettudomány) 16: 233-243. (in Hungarian with English Summary)

Keve, A. 1949. Rozmnoženi vlhy evropské (Merops apiaster) v Mad'arsku [Distribution of European Bee-eater (Merops apiaster) in Hungary]. - Sylvia 9-10: 97-98. (in Slovak with German Summary)

Keve, A. \& Udvardy, M. D. F. 1951. Increase and decrease of the breeding range of some birds in Hungary. - In: Hörstadius, S. (ed.) Proceedings of the $10^{\text {th }}$ International Ornithological Congress, Uppsala, June 1950. - Almqvist \& Wiksell, Uppsala pp. 468-476.

Kinzelbach, R., Nicolai, B. \& Schlenker, R. 1997. Der Bienenfreser Merops apiaster als Klimazeiger: Zum Einflug in Bayern, der Schweiz und Baden im Jahr 1644. - Journal für Ornithologie 138(3): 297-308.

Kis, E. 1978a A Hódmezővásárhely környéki homokbányák fészkelö madarai [Breeding birds in sand-pits near Hódmezővásárhely]. - Madártani Tájékoztató (szeptember-október): 19-20. (in Hungarian)

Kis, E. 1978b Partifecske felmérés Hódmezővásárhely környékén [Survey of Sand Martin near Hódmezővásárhely]. - Madártani Tájékoztató (márciusáprilis): 1. (in Hungarian)

Kovács, Zs. 1981. A gyurgyalagok helyzete Pécelen [European Bee-eaters in Pécel]. - Madártani Tájékoztató (október-december): 221-222. (in Hungarian)

Krištín, A. \& Petrov, T. 1997. Bee-eater Merops apiaster. - In: Hagemeijer, W. J. M. \& Blair, M. J. (eds.) The EBCC Atlas of European Breeding Birds. Their Distribution and Abundance, T \& AD Poyser, London pp. 432-433.
Krištofík, J., Mašán, P. \& Šustek, Z. 1996. Ectoparasites of Bee-eater (Merops apiaster) and arthropods in its nests. - Biologia Bratislava 51(5): 557570 .

Laczik, D. 1996. A gyurgyalag (Merops apiaster) táplálkozási szokásainak és viselkedésének vizsgálata [Study of the foraging and behavior of European Bee-eater (Merops apiaster)]. - Diplomamunka (Erdészeti és Faipari Egyetem, Erdőmérnöki Kar, Erdővédelemtani Tanszék), Sopron (in Hungarian)

Lajtmann, J. (szerk.) 1998. Gyurgyalag-program a Pannonhalmi-dombságon [European Bee-eater project in Pannonhalma Hills]. - Reflex Környezetvédö Egyesület, Győr (in Hungarian)

Lenner, J. 1982. Gyurgyalagok (Merops apiaster) vonulása Sárisápon 1981 őszén [Migration of European Bee-eaters (Merops apiaster) during autumn 1981 in Sárisáp]. - Madártani Tájékoztató (április-szeptember) p. 154. (in Hungarian)

Lenner, J. 1983. Gyurgyalag (Merops apiaster) költési adatok a sárisápi bányamedencéből (1982) [Breeding data of European Bee-eater (Merops apiaster) in pit-basin of Sárisáp (1982)]. - Madártani Tájékoztató (január-június): 35-36. (in Hungarian)

Leposa, J. 1980. Gyurgyalagok megtelepedése a pacsai homokbányában és egy használaton kívüli hévízi kőbányában [Breeding of European Bee-eaters in sand-pit of Pacsa and abandoned stone-pit of Hévíz]. - Madártani Tájékoztató (július-szeptember): 49. (in Hungarian)

Lessels, C. M. 1991. Helping at the nest in European Bee-eaters: who helps and why? - In: Blondel, J., Gosler, A., Lebreton, J-D. \& McCleery, R. (eds.) Population biology of Passerine birds. - SpringerVerlag, Berlin pp. 357-368.

Lessels, C. M. \& Avery, M. I. 1989. Hatching asynchrony in European Bee-eaters Merops apiaster. Journal of Animal Ecology 58: 815-835.

Lessels, C. M. \& Krebs, J. R. 1989. Age and breeding performance of European Bee-eaters. - The Auk 106(3): 375-382.

Lessels, C. M., Avery, M. I. \& Krebs, J. R. 1994. Nonrandom dispersal of kin: why do European Bee-eater (Merops apiaster) brothers nest close together? - Behavioral Ecology 5: 105-113.

Lokcsánszky, A. 1935. A Tolna megyei gyurgyalagtelepek [European Bee-eater colonies in county Tolna]. - Aquila 38-41: 179-186. (in Hungarian with German Summary)

Lopes, I., Sedlmayr, A., Moreira-Sanots, M., Moreno-Garrido, I., Blasco, J. \& Ribeiro, R. 2010. European Bee-eater (Merops apiaster) populations under arsenic and metal stress: evaluation of 
exposure at a mining site. - Environmental Monitoring and Assessment 161(1-4): 237-245. doi: 10.1007/s10661-008-0741-4.

Magyar, G., Hadarics, T., Waliczky, Z., Schmidt, A., Nagy, T. \& Bankovics, A. 1998. Magyarország madarainak névjegyzéke [An annotated list of the birds of Hungary]. - KTM Természetvédelmi Hivatal Madártani Intézete, Magyar Madártani és Természetvédelmi Egyesület, Winter Fair, Budapest-Szeged (in Hungarian with English Summary)

Marks, B. D., Weckstein, J. D., Robert, G. \& Moyle, R. G. 2007. Molecular phylogenetics of the Beeeaters (Aves: Meropidae) based on nuclear and mitochondrial DNA sequence data. - Molecular Phylogenetics and Evolution 45: 23-32. doi:10.1016/j.ympev.2007.07.004

Máry, Gy. 1929. A gyurgyalag fészkelése Füzfőn [Breeding of European Bee-eater in Füzfö]. Aquila 34-35: 375. (in Hungarian with German Summary)

McCullagh, P. \& Nelder, J. A. 1989. Generalized linear models, $2^{\text {nd }}$ ed. - Chapman $\&$ Hall, London

Merán, F. 1947. Méhészgyurgyalagok Csákberény környékén ['Bee-keeper' European Bee-eaters near Csákberény]. - Nimród Vadászlap 2(11): 175. (in Hungarian)

Mercsák, J. L.-né \& Mercsák, J. L. 1980. A tokaji Nagykopasz madárvilága [Avifauna of Nagykopasz Hill of Tokaj]. - Madártani Tájékoztató (január-március): 15-17. (in Hungarian)

Mile, D. 1964. Gyurgyalag telep a Tiszántúlon [European Bee-eater colony in Tiszántúl]. - Aquila 6970: 268. (in Hungarian with German Summary)

Mlíkovský, J. 2009. Middle Pleistocene birds of Hundsheim, Austria. - Journal of the National Museum (Prague), Natural History Series 177(7): 69-82.

Molnár, L. 1950. A gyurgyalag Körmend határában [European Bee-eater near Körmend]. - Aquila 51-54: 167. (in Hungarian with German Summary)

Munteanu, D. 1998. The status of birds in Romania. - Romanian Ornithological Society, Cluj-Napoca

Murin, B., Krištín, A., Darolová, A., Danko, ک̌. \& Kropil, R. 1994. Početnost' hniezdnych populácii vtákov na Slovensku [Breeding bird population sizes in Slovakia]. - Sylvia 30: 97-105. (in Slovak with English Summary)

Nagy, K. 1996. A gyurgyalag-populáció vizsgálata a Felső-Tisza mentén [Study of a European Bee-eater population along the Upper Tisza]. - Tudományos Diákköri dolgozat (Bessenyei György Tanárképző Főiskola, Állattani Tanszék), Nyíregyháza (in Hungarian)

Nagy, K., Szép, T., Bagdi, A. \& Gyurácz, J. 2008. A gyurgyalag (Merops apiaster) fészkelő állomá- nyának helyzete Magyarországon (1997-2003) [Status of the European Bee-eater breeding population in Hungary (1997-2003)]. - MME 6. Tudományos Ülése, mme-monitoring.hu/php/ dl.php?drid=1443. Download on 30.04.2013. (in Hungarian)

Nagy, L. 1979. Adatok Dorog és környékének madárvilágához [Data about avaifauna of Dorog an its area]. - Madártani Tájékoztató (április-június): 28-29. (in Hungarian)

Nagy, M. 2000. Kifüstölte a védett gyurgyalagokat. [Smoke killed the protected European Bee-eater]. - Kisalföld 55(158): 7. (in Hungarian)

Pannekoek, J. \& van Strien, A. J. 2001. TRIM 3 Manual. Trends and indices for monitoring data. Research paper no. 0102.

Papp, L. 1980. Az isaszegi gyurgyalag-állomány az utóbbi 5 évben [European Bee-eater population of Isaszeg in the last five years]. - Madártani Tájékoztató (április-június): 37. (in Hungarian)

Papp, L. 1984. A gyurgyalag-állomány (Merops apiaster) emelkedés Isaszegen [Increasing European Bee-eater (Merops apiaster) population in Isaszeg]. - Madártani Tájékoztató (október-december): 205. (in Hungarian)

Páldy, G. 1935. A gyurgyalag fészkelése Mezőkomáromnál 1934-ben [Breeding of European Bee-eater near Mezőkomárom in 1934]. - Aquila 38-41: 353. (in Hungarian with German Summary)

Páldy, G. 1939. A gyurgyalag fészkelése Mezőkomáromnál 1937-ben [Breeding of European Bee-eater near Mezőkomárom in 1937]. - Aquila 42-45: 675. (in Hungarian with German Summary)

Petrescu, A. \& Adam, C. 2000. Carnus hemapterus Nitzsch, 1818 (Diptera: Carnidae) parasite on $\mathrm{Me}$ rops apiaster L. (Aves: Meropida) in Southern Romania. - Travaux du Musturn Natioilal d'Histoire Naturelle 'Grigore Antipa' 43: 305-322.

Petrescu, A. \& Adam, C. 2001. Interspecific relations in the populations of Merops apiaster L. (Aves: Coraciiformes) of Southern Romania. - Travaux du Musturn Natioilal d'Histoire Naturelle 'Grigore Antipa' 43: 305-322.

Porgányi L. 1935. Gyurgyalag fészkelése Mohács vidékén [Breeding of European Bee-eater near Mohács]. - Aquila 38-41: 353-354. (in Hungarian with German Summary)

Purger, J. J. 2001. Numbers and breeding distribution of the Bee-eater Merops apiaster in province Voivodina (northern Serbia) between 1987 and 1990. - Vogelwelt 122: 279-282.

Radetzky, J. 1966. „Madárváros” - a földben [ 'Bird town' - in the ground]. - Élet és Tudomány 21(21): 987-991. (in Hungarian) 
Radetzky, J. 1979a Faunisztikai adatok a Velencei-tó tágabb környékéröl [Avifaunistical data around the Lake Velence]. - Madártani Tájékoztató (július-szeptember): 26-27. (in Hungarian)

Radetzky, J. 1979b Szétszóródott gyurgyalagtelep [Scattered European Bee-eater colony]. - Madártani Tájékoztató (április-június): 37-38. (in Hungarian)

Radványi, O. 1936. A gyurgyóka [European Bee-eater]. - Búvár 2(9): 604-606. (in Hungarian)

Radványi, O. 1939. Gyurgyalag fészkelése Simontornyán [Breeding of Bee-eater in Simontornya]. Aquila 42-45: 674-675. (in Hungarian with German Summary)

Radványi, O. 1950. Madártani jegyzetek a Hegyalja vidékéröl [Ornithological records from the environs of Hegyalja]. - Aquila 51-54: 171. (in Hungarian with English Summary)

Radványi, O. 1964. Megfigyelések gyurgyalag telepeken [Observations notes on the Bee-eater]. Aquila 69-70: 267. (in Hungarian with English Summary)

Ragats, Zs. 2001. A gyurgyalag (Merops apiaster) 2000. évi fészkelőállományának felmérése Györ-Moson-Sopron megyében [Survey of the $2000^{\text {th }}$ annual European Bee-eater breeding population in county Győr-Moson-Sopron]. - Szakdolgozat, Berzsenyi Dániel Főiskola, Szombathely (in Hungarian)

Rainer, I. 1930. Gyurgyalag Mátyásföldön [Bee-eater in Mátyásföld]. - Kócsag 3(3-4): 67. (in Hungarian with German Summary)

Rakha, M. A. \& Kandeel, M. M. H. 1983. Acarophenax meropsi $\mathrm{n}$. sp., from the European Bee-eater, Merops apiaster in Egypt (Acari: Tarsonemida). - Acarologia 24(3): 295-297.

Rakonczay, Z. (szerk.) 1997. Göcsejtől Mohácsig [From Göcsej to Mohács]. A Dél-Dunántúl természeti értékei. - Mezőgazda Kiadó, Budapest (in Hungarian)

Randik, A. 1957. A gyurgyalag fészkelése Vámosmikola határában [Breeding of the Bee-eater in Vámosmikola]. - Aquila 63-64: 290. (in Hungarian with English Summary)

Rékási, J. \& Haraszthy, L. 2005. Adatok a gyurgyalag (Merops apiaster) táplálkozásához köpetei alapján [Data on the diet of European Bee-eaters (Merops apiaster) based on pellet studies]. - Aquila 112: 223-236. (in Hungarian with English Summary)

Réz, E. 1929. A gyurgyalag fészkelése Nógrádban [Breeding of the Bee-eater in county Nógrád]. Aquila 34-35: 374-375. (in Hungarian with German Summary)

Réz, E. 1932. A gyurgyalagok fészektelepei Diósjenő környékén [Bee-eater breeding colonies in the en- viron of Diósjenő]. - Kócsag 5(3-4): 112-115. (in Hungarian with German Summary)

Sághy, A. 1942a Faunisztikai adatok Esztergom megyéböl [Avifaunistical data from the county Esztergom]. - Aquila 46-49: 464. (in Hungarian with German Summary)

Sághy, A. 1942b Gyurgyalagokról [Bee-eater]. - Nimród Vadászlap 3(28): 441-442. (in Hungarian)

Sághy, A. 1955. Adatok a Gerecse-hegység és a Középső-Duna madárvilágához [Contributions to the bird-life of Gerecse-Mountains and the middle Danube (NE Pannony, Central-Hungary]. - Aquila 59-62: 191-200. (in Hungarian with English Summary)

Sághy, A. 1978. A süttői gyurgyalag állomány 1978ban [Bee-eater population of Süttő in 1978]. Madártani Tájékoztató (november-december): 21-22. (in Hungarian)

Sapir, N., Wikelski, M. \& Avissar, R. 2011. Timing and flight mode of departure in migrating European Bee-eaters in relation to multi-scale meteorological processes. - Behaviour Ecolology and Sociobiology 65: 1353-1365. doi 10.1007/ s00265-011-1146-x

Schenk, J. 1935. Merops apiaster L. Mezőkomáromnál [Merops apiaster colony in Mezőkomárom]. - Aquila 38-41: 353. (in Hungarian with German Summary)

Sík, E., Süveges, Gy., Szandai, J., Molnár, J. \& Román, T. 1955. Még egyszer a gyurgyalagról [Once more on the Bee-eater]. - Üzemi és Háztáji Méhészet 3(10): 195-196. (in Hungarian)

Smalley, I., O’Hara-Dhand, K., McLaren, S., Svircev, Z. \& Nugent, H. 2013. Loess and Bee-eaters I: Ground properties affecting the nesting of European Bee-eaters (Merops apiaster L., 1758) in loess deposits. - Quaternary International 296: 220-226. http://dx.doi.org/10.1016/j.quaint.2012.09.005

Snow, D. W. \& Perrins, C. M. 1998. The Birds of the Western Palearctic. - Concise Edition based on The Handbook of the Birds of Europe, the Middle East, and North Africa. Vol. 1. Non-Passerines. Oxford University Press, Oxford

Söreghy, J. 1934. A gyurgyalagról Merops apiaster Szatmár megyében [Bee-eater Merops apiaster in Mezőkomárom]. - Kócsag 7(1-4): 75-76. (in Hungarian with German Summary)

Sőregi, J. 1955. Darujárás Nádudvaron, gyurgyalag a Bodrogközben [A great number of Cranes at Nádudvar, Bee-eaters near the river Bodrog]. Aquila 59-62: 381. (in Hungarian with English Summary)

Sterbetz, I. 1959. Mezei veréb és gyurgyalag megfigyelések Cegléd környékén [Observations on the Tree Sparrow and Bee-eater in the surroundings 
of Cegléd]. - Aquila 65: 331. (in Hungarian with English Summary)

Szalczer, A. 1982. Gyurgyalag (Merops apiaster) földi fészkelése Hajós környékén [Bee-eater (Merops apiaster) nesting in ground-holes near Hajós]. Aquila 88: 131. (in Hungarian with English Summary)

Szederkényi, N., Faust, R., Varga, G., Tárnoky, E., Dékány, D. \& Koltay, P. 1955. A gyurgyalag kártevése a méhesben [The damage of Bee-eaters in apiaries]. - Üzemi és Háztáji Méhészet 3(7): 125-126. (in Hungarian)

Szép, T., Nagy, K., Nagy, Zs. \& Halmos, G. 2012. Population trends of common breeding and wintering birds in Hungary, decline of long-distance migrant and farmland birds during 1999-2012. Ornis Hungarica 20(2): 13-63.

Szijj, J. 1955. A gyurgyalag 1949. évi fészkelő telepei hazánkban [The colonies of the Bee-eater in Hungary in the year 1949]. - Aquila 59-62: 185-190. (in Hungarian with English Summary)

Tapfer, D. 1957. Über die Verbreitung und Brutbiologie des Bienenfressers in Ungarn [Distribution and breeding biology of the Bee-eaters in Hungary]. - Der Falke 4(1): 3-5. (in German with English Summary)

Tapfer, D. 1978. A gyurgyalag (Merops apiaster L.) a Keleti-Bakonyban [European Bee-eater $(\mathrm{Me}$ rops apiaster L.) in East Bakony]. - A Veszprém Megyei Múzeumok Közleményei (Természettudomány) 13: 77-80. (in Hungarian with German Summary)

Tarján, T. 1929. Gyurgyalag (Merops apiaster) a Balaton vidékén [European Bee-eater (Merops apiaster) in the surroundings of Lake Balaton]. Aquila 34-35: 375. (in Hungarian with German Summary)

Thóbiás, Gy. 1943. Merops apiaster [Merops apiaster]. - Aquila 50: 409. (in Hungarian with German Summary)

Török, I. H. 1999. European Bee-eaters and the occupants of their burrows: friends or enemies? - Bird Numbers 8: 16-17.

Udvardy, D. F. M. 1969. The concept of faunal dynamism and the analysis of an example (Avifaunal dynamism in the Carpathian Basin). - Bonner Zoologische Beitrage 20: 1-10.
Uhde, Á. 1905. A gyurgyalag rendszeres kóborlása [Regular wandering of European Bee-eater]. - Aquila 12: 340-341. (in Hungarian with German Summary)

Urbán, S., Túri, K., Vas, Z. \& Fuisz, T. I. 2013. A successful habitat reconstruction effort, the short history of the European Bee-eater (Merops apiaster) colony at Albertirsa (Hungary). - Ornis Hungarica 21(2):

Václav, R. 2000. Forms and variation of helping in the European Bee-eater (Merops apiaster). - Biologia Bratislava 55(5): 563-570.

Vagg, R. \& Hepworth, H. 2006. Migratory Species and Climate Change: Impacts of a Changing Evironment on Wild Animals. - UNEP/CMS. Bonn

van Strien, A. J., Pannekoek, J. \& Gibbons, D. W. 2001. Indexing European bird population trends using results of national monitoring schemes: a trial of a new method. - Bird Study 48: 200-213.

Varga, F. 1982. Gyurgyalagok (Merops apiaster) költése a Medves hegység déli és keleti nyúlványai között [Breeding of European Bee-eater (Merops apiaster) in Medves Mountains]. - Madártani Tájékoztató (április-szeptember): 162-163. (in Hungarian)

Vásárhelyi, I. 1957. Madártani adatok a Bükkből [Ornithological data from the Bükk-mountains (Northern Hungary)]. - Aquila 63-64: 290-291. (in Hungarian with English Summary)

Vertse, A. 1939. Újabb gyurgyalag fészkelések [New breedings of European Bee-eater (Merops apiaster)]. - Aquila 42-45: 675. (in Hungarian with German Summary)

Wagner, J. 1935. Merops apiaster L. Pécs közelében [Merops apiaster L. near Pécs]. - Aquila 38-41: 354. (in Hungarian with German Summary)

Yosef, R. 2010. Thermoregulatory behavior in migratory European Bee-eaters (Merops apiaster). The Wilson Journal of Ornithology 122(2): 378380. doi: http://dx.doi.org/10.1676/09-135.1

Yosef, R., Markovets, M., Mitchell, L. \& Tryjanowski, P. 2006. Body condition as a determinant for stopover in Bee-eaters on spring migration in the Arava Valley, southern Israel. - Journal of Arid Environments 62: 401-411. 